\title{
BIOMETRIC RECOGNITION AS A SECURITY MECHANISM USING GPS SYSTEMS
}

\section{SANTIAGO RUBIÑOS, JUAN MENDOZA, FREEDY SOTELO, ABILIO CUZCANO, EDWIN HUARCAYA, CAROLINA JIMÉNEZ, EDISON CHOQUE}

Unidad de Posgrado de la FIEE, Universidad Nacional del Callao, Lima, Perú

\begin{abstract}
This project consists of a biometric authentication system for iris recognition to recognize that only the owner and the people authorized by it can drive the vehicle, otherwise if the system does not recognize the identity or is forced to start, a message is sent Alerts the owner and the nearest police station, followed by a GPS tracking of the car. Therefore, we meet the objective of reducing vehicle theft rates since the proposed system is accessible and scalable. KEYWORDS: Biometrics, Security, GPS, Monitoring, Authentification
\end{abstract}

Received: Jun 08, 2020; Accepted: Jun 28, 2020; Published: Sep 26, 2020; Paper Id.: IJMPERDJUN20201443

\section{INTRODUCTION}

We are currently experiencing the problem of aggravated crime to the point that according to the INEI in the Peru 19084 complaints have been registered for car thefts from 2009 to 2018 [1] that is why we are concerned because of crime we are forced to use the technology to avoid these problems.

For this we will use one of the most reliable on the market which is iris recognition that in addition to being one of the parts of the body that suffers less variations over time, the iris of each being human is unique and unrepeatable because the structure of the eye is very complex. The recognition error rate of iris is $1 / 1200000$, in addition to being used for identification in large masses. [2]

This system has a platform where the vehicle owner records their biometric data based on the iris and contact (cell), at the same time the owner will have a password and login user that will allow you to register or eliminate more drivers from the same vehicle.

After the iris biometric registration has already been given, goes to the treatment, processing and storage process of iris using Matlab software. Once having the database of the biometric registry, we go to the installation of the system in the vehicle.

The system implemented in the car will have a webcam, a Curiosity Nano PIC18F47K42 that will be the system controller, a SIM808 Gateway module for sending alert messages and GPS tracking. alert system will be activated if an iris is detected identified or the vehicle is forced to start, then an alarm message will be sent to the owner's cell phone previously registered and a call to the central Police emergencies 105, followed by GPS tracking of the vehicle in real time. 


\section{BIOMETRIC IDENTIFICATION}

It is a morphological characteristic perfectly circular presenting the properties mathematically "more individual and unique" of all up to date investigated by biologists and engineers (even more than DNA). Thus, it can be said that his structure will remain stable and invariant throughout lifetime. Morphologically, it is made up of a Visible structure in the form of a colored ring, protected by the cornea and the aqueous humor, which results from the combination of the crown, filaments, muscle fibers, radial grooves, etc. It should be noted that the iris and pupil do not respond to concentric circles (do not have the same center). [3]

In the case of the iris we find: [4] : It is an element that remains unchanged throughout all the life of the individual, besides being hardly modifiable due to an accident, or voluntarily through any type of surgery or technique.

The dilation and contraction of the pupil involves verify that obviously we are facing a living or real person; something that constitutes added value to the security of this system. It is possible to obtain the necessary data present in this element without making physical contact with the person to identify. The location of the iris in the eye allows it to be protected, and thanks to the cornea it does not suffer any type of wear.

It is a unique element, as unique as they do not exist two equal irises, which also includes differences between these elements in the eyes of the same person: the iris of our right eye is different from the iris of our eye left.

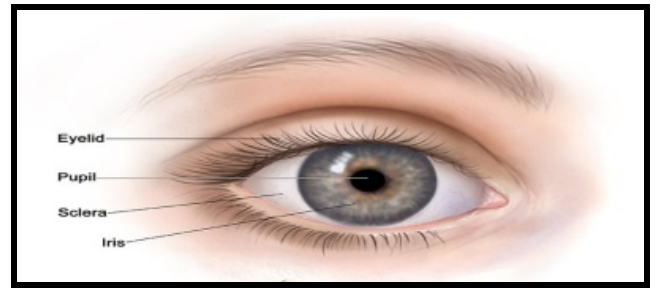

Figure 1: Ocular Structure (Source: Photonostra).

\section{GSM}

Four subsystems are found in the GSM network main each of which contains a certain amount of functional units which are connected to the another through interfaces. The main subsystems of the network and the elements are [6]:

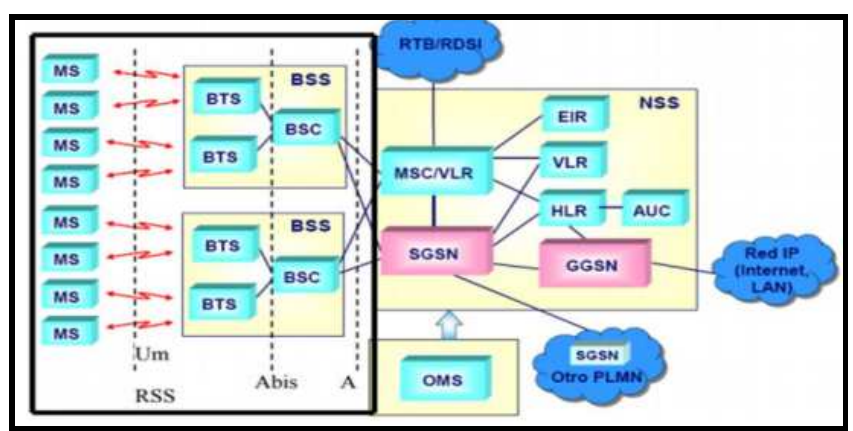

Figure 2: GSM Network.

GSM uses 124 frequency channels, each of they use an 8 slot TDM system: [7] 


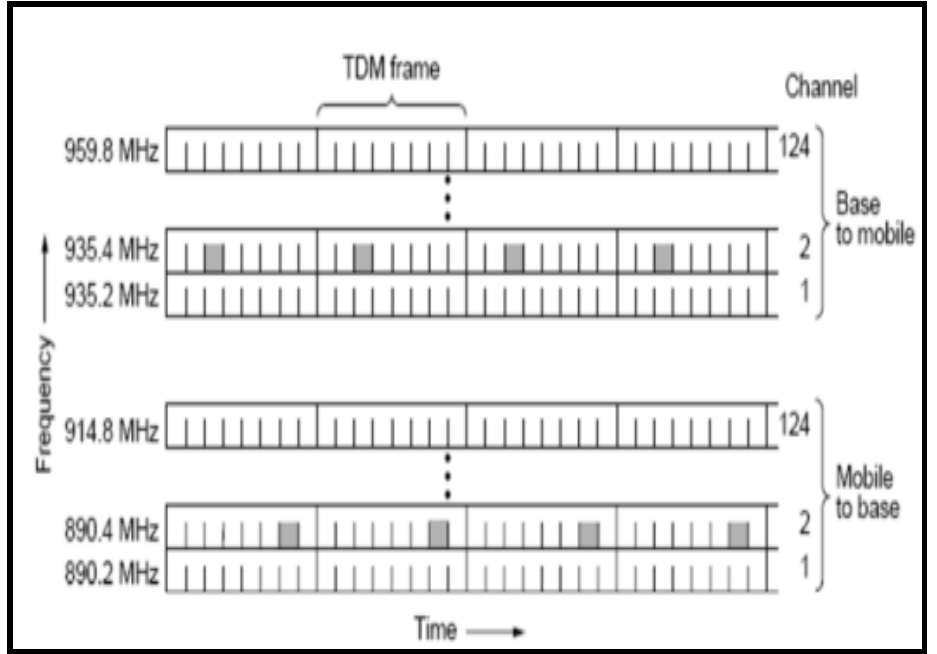

Figure 3: GSM Frequency Channels.

\section{GEOLOCATION SYSTEM}

Geolocation devices allow know where on the globe are the devices These systems generally work by sending signals to different receivers and these return the signal. triangulation based on the delay and intensity of these signals, allows to determine the position of the device issuer. [9]

Most of the computer programs that provide position information in real time understand and expect the data to be in format NMEA. This data includes the complete PVT solution (position, speed, time) calculated by the receiver GPS.

The most important NMEA sentences include the GGA that provides the current Fix data, the RMC which provides the minimum information of gps sentences and the GSA that provides the satellite status data. [10]

\section{METHODS \& MATERIALS}

The System has four phases: Registration, Identification, Alert message and GPS tracking. Due to the length of the circuit it is represented using a flow chart in figure 2 where We will explain the stages of the System process that guarantees the safety of the vehicle.

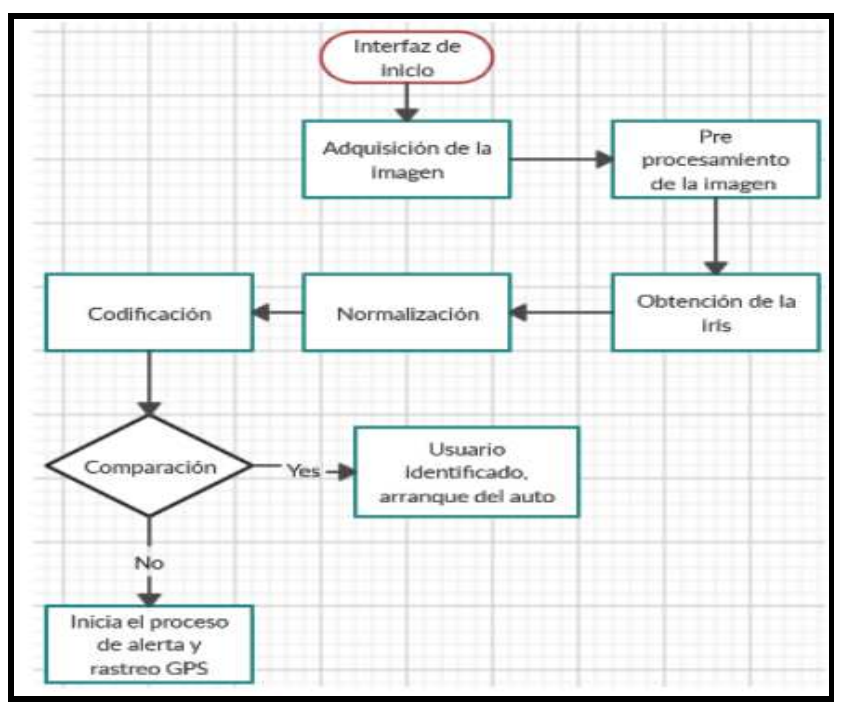

Figure 4: System Flow Diagram (Source: Own). 


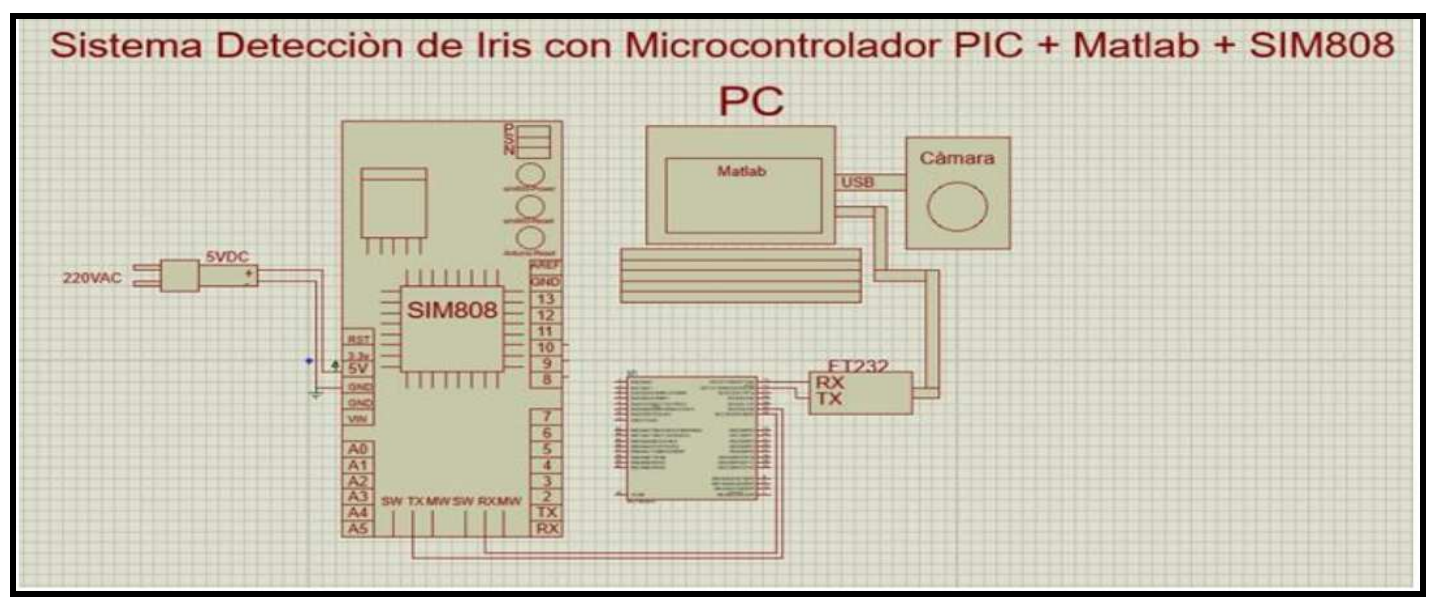

Figure 5: Representation in System Proteus (Source: Own).

There are many acquisition systems for images, most with sophisticated ergo equipment in this project we propose a system based on a Low cost conventional digital camera and a low cost and easy access GPRS System. In the next picture the simulation of our System in proteus is shown.

\section{PLATFORM REGISTRATION PHASE}

This is the first stage of the System where the vehicle owner has to register on the platform, will have a login and username, then will go through the iris data collection process, you can also add or remove drivers from your car.

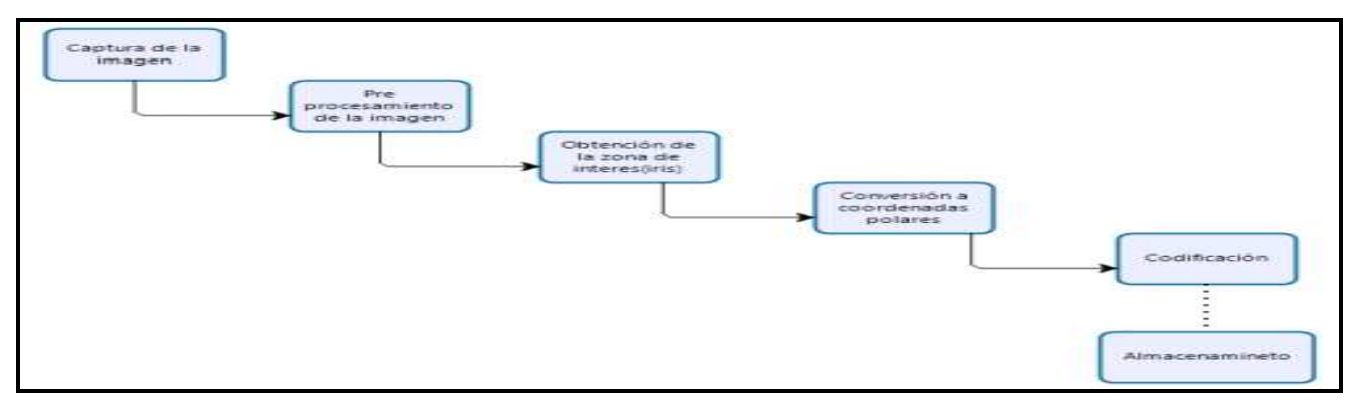

Figure 6: Sequence for Obtaining and Registering the User's Iris (Source: Own).

For the startup interface it was programmed in the java language using the Eclipse Mars software, with which the graphical interface (gui), data storage (fix), data encapsulation (class). In addition to the use of a library for data validation.

In the following image we can see the driver registration platform, where you should put the name, surname, identification document, cell phone since to that number is where the message will be sent alert in a possible emergency case.

\section{IRIS RECOGNITION PHASE}

\section{Capture the Image}

The first step for user recognition through of the iris is the image taking. This step is essential since the development of the entire system will be influenced by quality of the image taken, so the image should: have good resolution, be focused and have good lighting. That is why a high camera is necessary. quality. [eleven] The Chinese Academy of Sciences-Institute of automation (CASIA) make various databases available free iris data. [11], [12], [13]. 


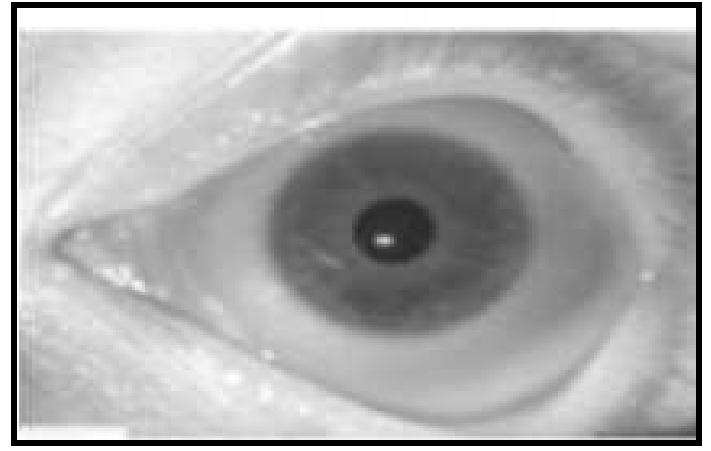

Figure 7: Iris from the CASIA Database.

\section{Pre-Processing}

As can be seen in fig. 6, the image not only contains the iris, but contains the pupil, the eyelid, eyelashes in addition to suffering any dilation or contraction due to lighting. It is for this reason that it is necessary an image processing before using it in the coding. With which there are 2 stages: [14]

Segmentation: the image of the iris is located. Normalization: it will allow us to compare different irises.

The proposed algorithm to locate these figures geometric uses two well-known techniques in the image processing, the Canny operator [15], [16], for edge detection, and the Transform of Hough [17], for the identification of parametric curves.

\section{Segmentation}

The first thing that is found is the circle or edge of the pupil, which will serve us later on knowing the radius of the pupil in addition to taking the center of the pupil as a reference for the iris (but these are not concentric). With which will generate a grayscale histogram ranging from 0 to 255 pixels, where 0 is black and 255 the whitest hue possible, this will help us to determine the threshold Because the pupil is the darkest part, when binarizing the image we will have the image fig. 13 (c). [14].

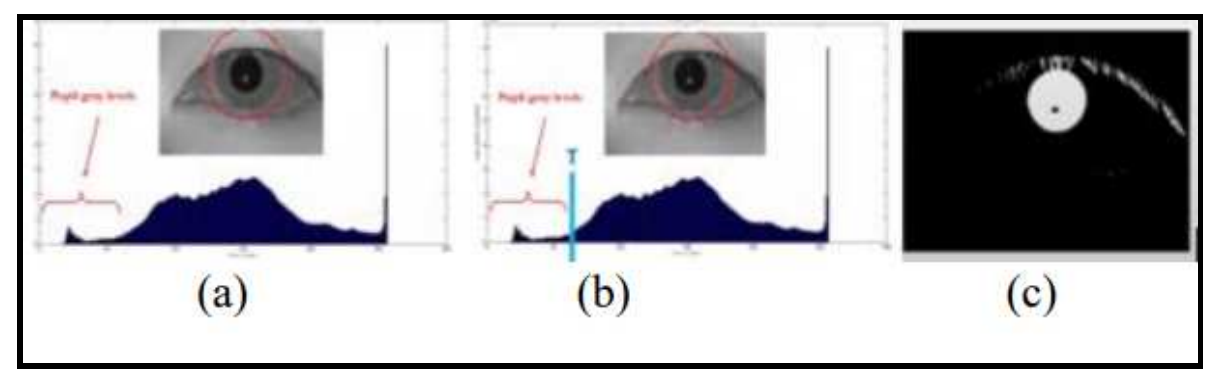

Figure 8: (A) Histogram of the Image (B) Determination of the Threshold (C) Conversion of Pixels Less than the Threshold in White (Source: Trujillo-Peru Biometrics Presentation).

In the worst case the top tab is turns white whereupon a median filter is applied to remove it. Fig. 13 (c). [14]. 


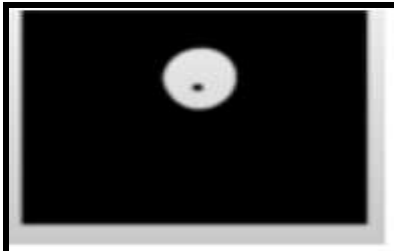

(a)

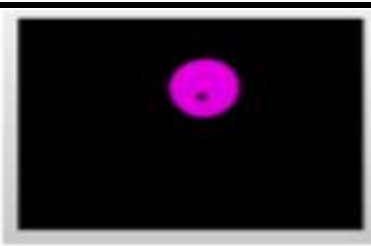

(b)

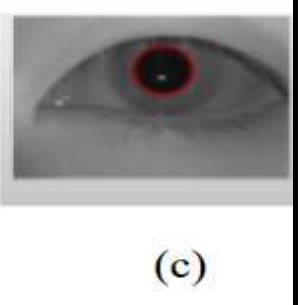

Figure 9: (A) The Tab Was Removed (B) The Graph Theory Algorithm (C) We Get the Edge the Pupil (Source: Trujillo-Peru Biometrics Presentation).

The second thing to do is find the edge of the iris, to be able to do it first a smoothing of the image fig. 15 (a), followed by the application of the Canny is what is one of the most powerful and exact.fig.15 (b), now the transform of Hough which worked with the geometric structure the what will be the circle. [11], [12], [14].

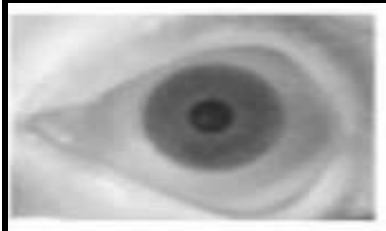

(a)

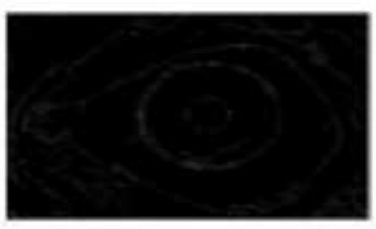

(b)

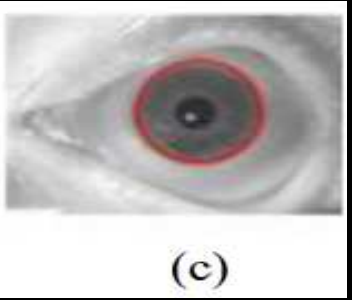

(c)

Figure 10: (A) Smoothed Image (B) Detection of Edges (C) Circumference Detection. (Source: Paper of Biometrics Trujillo-Peru).

Now the eyelids are located and for this task makes use of Canny again for edge detection, but only considering horizontal edges fig. 16 (a) and it remove the eyelids with the Hough transform, but this time applied to lines fig. 16 (b). [11], [14]

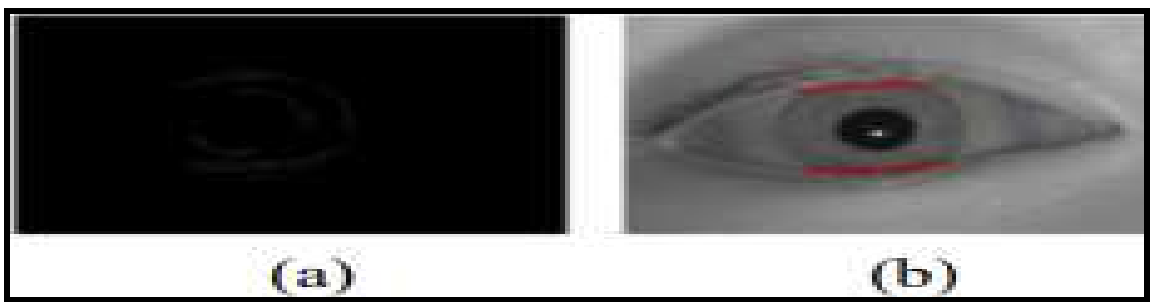

Figure 11: (A) Edge Detection, (B) Edge Detection Eyelid Lines. (Source: Biometrics Presentation Trujillo-Peru).

\section{Standardization}

Once the iris of the ocular region has been detected, this crown circular we proceed to convert it into a rectangle constant dimensions with which it can be compared to other irises. In this way various images of it irises under different light factors will have the same spatial characteristics.

That is why the normalization of the iris with the use of Daugman's algorithm, called homogeneous model "Ruber sheet" [18], which defines the area of the circular crown as polar coordinates and not Cartesian. Each point on the iris is assigned a coordinate $(r, \theta)$ where $r$ varies from $[0,1]$ and $\theta$ from $[0,2 \pi]$. He Redrawn of the iris image can be represented as: 
$\mathrm{I}(\mathrm{x}(\mathrm{r}, \theta), \mathrm{y}(\mathrm{r}, \theta)) \rightarrow \mathrm{I}(\mathrm{r}, \theta) \ldots(2)$

The image is normalized in such a way that it is it becomes rectangular since it is in charge of unwrapping the iris region, on the vertical axis is represented by the radius (r) and the horizontal axis by the angle $(\theta)$.

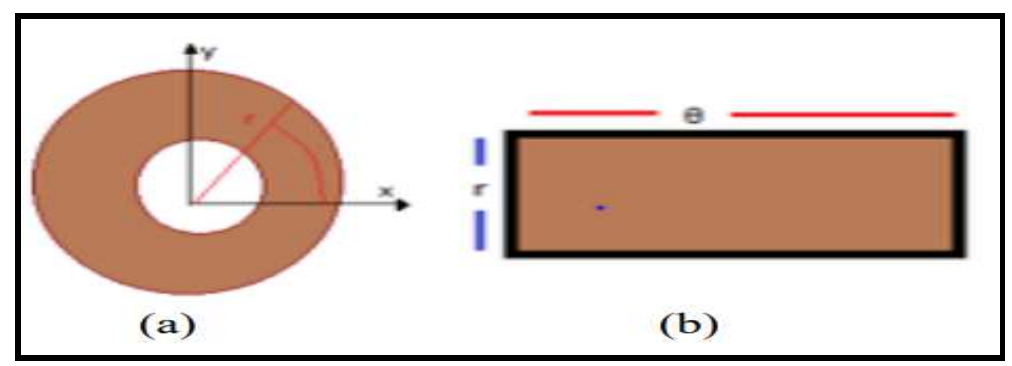

Figure 12: (A) Original Image (B) Normalized Image.

Apart from generating the normalized iris image an additional template called noise template is generated (template in which the iris obstructed by the eyelid) or also called a mask that will serve to subsequent comparisons.

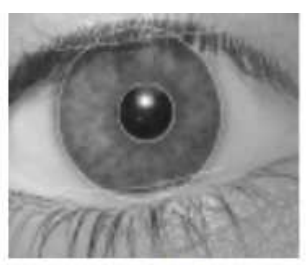

(a)

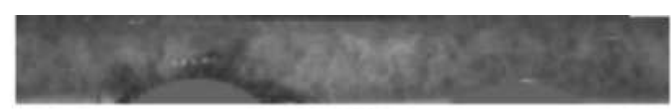

(b)

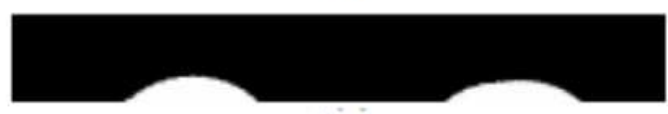

(b)

Figure 13: (A) Image of the Segmented Iris (B) Iris Normalized (C) Noise Template (Source: Argentina Magazine Student Work).

\section{RESULTS}

Los resultados demuestran que se puede realizar el reconocimiento biométrico a través del análisis de la imagen de iris, para el control de los altos. El estudio de la imagen de iris se desarrolló gracias a las técnicas de procesamiento de imágenes, con lo cual se pudo identificar al duelo de automóvil para que pueda encender el automóvil. Un agregado a la investigación es la conexión con otras disciplinas, y entre ellas encontramos los sistemas de alerta y rastreo por GPS. En diseño presentado así como la metodología permiten escalar y poder ser aplicado a situaciones reales.

A continuación presentamos los resultados de las etapas de codificación, señales de emergencia y traqueo por GPS:

\section{CODING}

After you have processed segmented and normalized of the image thus obtaining the corresponding templates, it is necessary to obtain biometric characteristics and their subsequent coding binary so that a unique code is generated in this way for each user.

To obtain this binary coding, will make use of the one-dimensional Log-Gabor filters in which the normalized image will be decomposed into a group of one-dimensional signals, then each signal is filtered using the Log-Gabor filter. Finally, each signal will be quantified in 4 different levels according to its location and end. [11] 


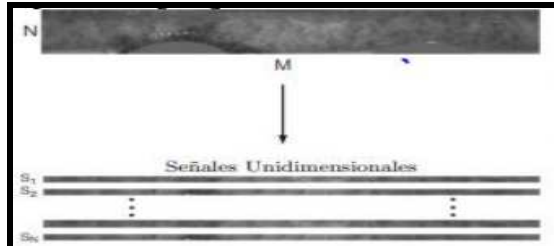

(a)

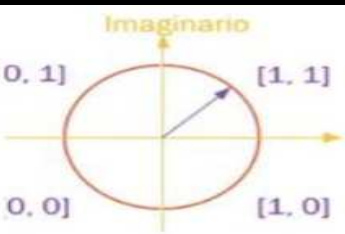

(b)

Figure 14: (A) Decomposition of the Image Normalized (B) Phase Encoding (Source: Journal Argentina of Student Works).

In this way the unique template for each user fig. 20, which will finally be stored in our database and its subsequent use for validation of the user.

\begin{tabular}{|l|l|}
\hline Iris Template & \multicolumn{1}{|c|}{} \\
01000010111101010010101111010100101011010101010100 \\
10100111000111101110100010011000110110110001011110 \\
\hline
\end{tabular}

Figure 15: Unique User Template (Source: Presentation Of Biometrics Trujillo-Peru).

The use of this Log-Gabor filter is due to the smallest representation of images when the bandwidth is greater than one octave, the case being iris image which has a bandwidth greater than one eighth. [19]

\section{SENDING PHASE OF EMERGENCY SIGNAL}

This stage in the System is activated if the iris of the driver has not been registered or the engine of the vehicle is forced, so we use the module SIM808 gateway which we control with AT commands programmed in the Curiosity Nano pic with the PIC18F47K42 using the MpLABX program to send the alert messages to the owner's cell phone previously registered on the platform and the emergency call to the Police center.

\section{GPS TRACKING PHASE AT}

This stage of the System, once the Alert system. Begins GPS tracking in real time for which we use the internal GPS that has the SIM808 that It is a 2G-GPRS gateway and GPS at the same time, all this We program on the PIC18F47K42.

To get the coordinates of the vehicle, we use the NMEA frame which follows the following format:

\$ GPGGA, 123519,4807.038, N, 01131.000, E, 1,08,0.9,545.4, M, 46.9, M, * 47

Where:

4807.038, N Latitude 48 degrees 07.038 'N

01131.000, E Longitude 11 degrees 31.000 'E

1 Quality of arrangement

545.4, altitude M, meters, above the mean level of the sea

46.9, M Geoid height (mean sea level) About WGS84 


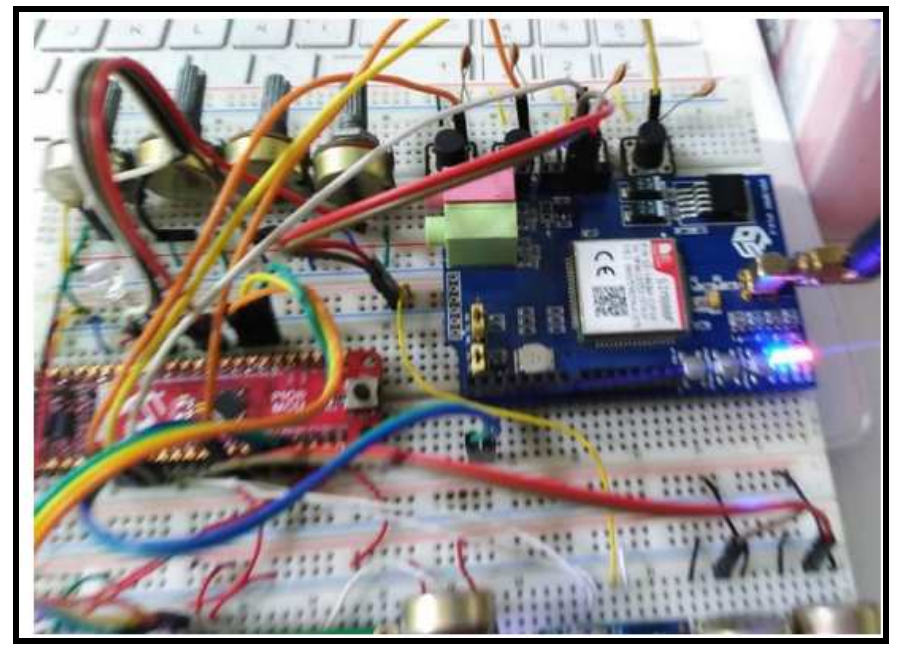

Figure 16: PIC18F47K42 and SIM800 Circuit (Source: Own).

\section{CONCLUSIONS}

Se concluye que al momento del registro biométrico en la plataforma, se registre e ingrese en promedio 10 fotografías de la iris, teniendo en consideración diferentes ángulos, iluminación y distancia focal. Este grupo de imágenes permitirá crear una base de datos de imágenes para mejorar el rendimiento del procesamiento de las imágenes con la finalidad de diferenciar el promedio del umbral que será utilizado en la mejora de la validación del usuario.

\section{REFERENCES}

1. El sistema planteado está probado en su etapa de prueba de concepto, quedando pendiente escalar hacia el uso práctico a una escala real.

2. INEI, "Estadísticas de robo de vehículos", Lima, Perú, 2018, [online] http://m.inei.gob.pelestadisticas/indicetematico/vehicletheft/

3. L. Escajedo, "Reconocimiento de Identificación de las personas mediante Biometrías estáticas y dinámicas", Universidad de Alicante, Alicante, España, 2015

4. V. E. Duró, "Evaluación de sistemas de reconocimiento Biométrico", Escuela Universitaria Politécnica de Mataró, Mataró, Barcelona, España.

5. Biometrics, "Identificación Biométrica a través del iris ocular", Valencia, España, 2020, [online] https://biometricson.com/identificacion-biometrica-atraves-del-iris-ocular /\#Procesado_de_la_imagen_capturada [

6. INEI, "Aumentó población que accedió a internet mediante teléfono celular de enero a marzo del 2018", Lima, Perú, 2018, [online] http://m.inei.gob.pe/prensa/noticias/aumento-poblacion-queaccedio-a-internet-mediante-telefono-celular-de-eneroamarzo-de-2018-10827/

7. R. R. Carlos. "Telefonía Celular y Protección de sus enlaces en Comunicaciones", Tesina, Departamento de Ingeniería Mecánica y Eléctrica, Instituto Politécnico Nacional, Distrito Federal, México, 2017.

8. UNNE, "Redes Celulares Inalámbricas", Universidad Nacional del Nordeste, Corrientes, Argentina. [online] http://exa.unne.edu.ar/depar/areas/informatica/telep roc/Comunicaciones/Presentaciones_Proyector/RedesCelula resInalambricas.pdf 
9. Simcom, “Datasheet SIM800F”, Shanghái, China, [online] https://datasheet.octopart.com/SIM800FSimcom-datasheet46771461.pdf

10. Gobierno de Navarra, "Uso de dispositivos móviles, (teléfonos móviles, Smartphones, ebooks, GPS y tablets)”, Navarra, España.

11. D.DePriest” Datos NMEA",National Marine Electronics Association, Tech.Rep.

12. L.D. Terissi, L. Cipollone and P. Baldino, "Sistema de Reconocimiento de iris", Revista Argentina. de Trabajos estudiantiles, vol. 1, $N^{\circ} 2$, marzo 2006.

13. B. M. Barbancho, "Propuesta y evaluación de un sistema de reconocimiento de iris basado en filtros Sobel", Trabajo Fin de Grado, Departamento de ingenieros de telecomunicaciones, Universidad Politécnica de Madrid, Madrid, España, junio 2016.

14. A. L. Vera, "Autentificación de un usuario basado en la biometría facial del iris empleando patrones de reconocimiento de imagen para clientes móviles ANDROID”, Tesis de grado, Facultad de ciencias Puras y Naturales, Universiad Mayor de San Andrés, La Paz, Bolivia, 2015.

15. L. Florian and F. Carranza, "Reconocimiento del iris", Universidad Nacional de Trujillo, Trujillo, Perú,2006.

16. J. F. Canny, "Finding edges and lines in images," M. S. thesis, Mass. Inst. Technologies, 1983.

17. “A computational approach to edge detection," IEEE Transactions on Pattern Analysis and Machine Intelligence, vol. 8, pp. 679-698, 1986.

18. R. C. González and R. E. Woods, Tratamiento Digital de Imágenes. Wilmington, Delware: AddisonWesley / Diaz de Santo, 1996.

19. Daugman, J.(2007).Net methods in iris recognition. IEEE transactions on systems, Man and Cybernetics, Part B, 37(5), 11671175.

20. D. Field, "Relations between the statistics of natural images and the response properties of cortical cells," Journal of the Optical Society of America, vol. 4, no. 12, pp. 2379-2394, December 1987 